Jurnal Riset Agama

Volume 1, Nomor 2 (Agustus 2021): 308-322

DOI: $10.15575 /$ jra.v1i2.14569

https://journal.uinsgd.ac.id/index.php/jra

\title{
Dukungan Sosial bagi Penderita Disfungsional untuk Penguatan Kesehatan Mental: Studi Syarah Hadis dengan Pendekatan Psikologi Islam
}

\author{
Muhamad Azhan Azhari \\ Jurusan Ilmu Hadis, Fakultas Ushuluddin \\ UIN Sunan Gunung Djati Bandung, Indonesia \\ muh.azhan.azhari@gmail.com
}

\begin{abstract}
The purpose of this study is to discuss the hadith about mental health with a religious psychology approach. This research method uses a qualitative type through literature study and content analysis. The results and discussion of this study include a general view of mental health, hadith on mental health, and mental health with a religious psychology approach. The conclusion of this study is that mental health is related to psychotherapy through the practice of worship, in the sense that all kinds of teachings and rituals in religion can help heal mental disorders and religious teachings keep away from negative solutions. This research is expected to have enrichment for health and Islamic knowledge.
\end{abstract}

Keywords: Religion; Hadith; Mental; Psychology.

\begin{abstract}
Abstrak
Tujuan penelitian ini adalah membahas hadis tentang kesehatan mental dengan pendekatan psikologi agama. Metode penelitian ini menggunakan jenis kualitatif melalui studi pustaka dan analisis isi. Hasil dan pembahasan penelitian ini meliputi pandangan umum kesehatan mental, hadis tentang kesehatan mental, dan kesehatan mental dengan pendekatan psikologi agama. Kesimpulan penelitian ini bahwa kesehatan mental berkaitan dengan psikoterapi melalui amalan ibadah, dalam artian segala macam ajaran serta ritual dalam agama dapat membantu penyembuhkan gangguan mental dan ajaran agama menjauhkan dari penyelesaian negatif. Penelitian ini diharapkan memiliki pengayaan khazanah bagi kesehatan dan pengetahuan Islam.
\end{abstract}

Kata Kunci: Agama; Hadis; Mental; Psikologi. 
Jurnal Riset Agama, Volume 1, Nomor 2 (Agustus 2021): 308-322

Muhamad Azhan Azhari/ Dukungan Sosial bagi Penderita Disfungsional untuk Penguatan Kesehatan Mental: Studi Syarah Hadis dengan Pendekatan Psikologi Islam

\section{Pendahuluan}

Kondisi kesehatan dalam diri seseorang sangat perlu diperhatikan, bukan hanya fisik saja, melainkan kesehatan mental. Dengan sehatnya mental seseorang maka pola perilaku dan karakter dalam kehidupannya akan lebih positif (Ariadi, 2019a). Namun, pengkajian kesehatan mental dibutuhkan pendekatan yang relevan. Islam berdasarkan teks Al-Qur'an dan teks hadis sangat menekankan kesehatan mental di samping kesehatan fisik (Ma'rufah, 2015). Oleh karena itu, pendekatan psikologi agama sangat dibutuhkan dalam memahami teks Islam (Hamid, 2017), termasuk hadis Nabi Saw.

Sejumlah pakar telah melakukan penelitian berkenaan dengan kesehatan mental sebagaimana dalam tinjauan pustaka penelitian ini. Antara lain Salsabila, A. \& Masrus, M. S. (2020), "Peran Kgama dalam Kesehatan Mental: Kajian Psikologis atas Kisah Maryam binti Imran dalam Q.S. Maryam: 18-22," Akademika UIN Sunan Kalijaga Yogyakarta. Artikel ini menggunakan teori ayat al-Qur'an yang relevan yang merupakan jenis penelitian analisis dengan pendekatan deskriptif dan interpretatif. Hasil dan pembahasan artikel ini adalah untuk memperkuat keimanan dan ketuhanan melalui ibadah yang sesuai dengan ajaran Allah dan Rasul, sehingga dapat membimbing manusia menuju kebahagiaan dan kesehatan jiwa, serta memaksimalkan potensi manusia. Kesimpulan dari artikel ini adalah peran agama dalam memecahkan masalah kehidupan dan penyembuhan aspek psikologis Maryam binti Imran (Salsabila \& Masrur, 2020). Reza, F. I. (2015), “Efektivitas Pelaksaan Ibadah dalam Upaya mencapai Kesehatan Mental," Psikis : Jurnal Psikologi Islami. Artikel ini menggunakan hipotesis dekonstruksi, yang merupakan semacam eksplorasi subjektif dengan rencana hipotesis yang beralasan. Artikel ini berbicara tentang penelitian masa lalu oleh Christian Zwingmann, Dadang Hawari dan Larson yang mengungkapkan bahwa metodologi ketat berperan dalam mengalahkan masalah mental dan aktual individu. Artikel ini menganggap bahwa orang yang memahami dan menyukai tindakan dalam ibadahnya dapat menaklukkan masalah kehidupan yang mampu sehingga mereka pada umumnya akan memiliki kesehatan psikologis yang baik (Reza, 2016). Lazuardini I, H. A. (2019), "Relevansi Hadis Larangan Marah dengan Kesehatan Mental," AL-QUDS : Jurnal Studi Alquran dan Hadis. Artikel ini menggunakan teori psikologis yang merupakan jenis penelitian kualitatif dengan metode studi pustaka analisa. Hasil dan pembahasan artikel ini adalah untuk menemukan pentingnya yang terkandung dalam hadits marah yang dikonsentrasikan dari sudut mental. Artikel ini menjelaskan bahwa orang-orang lebih mungkin untuk mempertahankan perilaku mereka sepanjang kehidupan sehari-hari, dan menyalurkan hal-hal dengan baik dan tidak mudah terpengaruh oleh perasaan (Lazuardini I, 2019). 
Jurnal Riset Agama, Volume 1, Nomor 2 (Agustus 2021): 308-322

Muhamad Azhan Azhari/ Dukungan Sosial bagi Penderita Disfungsional untuk Penguatan Kesehatan Mental: Studi Syarah Hadis dengan Pendekatan Psikologi Islam

Berbagai penelitian terdahulu berharga dalam penyusunan kerangka berpikir penelitian ini. Kesejahteraan psikologis adalah kapasitas untuk menyesuaikan diri dengan orang lain dan masyarakat umum serta iklim tempat mereka tinggal (Ahmad, 2018). Kesehatan mental adalah pengakuan atas kesesuaian yang tulus antara unsur-unsur ruh, sama seperti kemampuan untuk menangani masalah-masalah adat yang terjadi, dan untuk merasakan kepuasan dan kapasitas diri sendiri secara pasti (Siregar, 2020). Kesehatan jiwa digambarkan secara rinci sebagai kekuatan akidah, bebas dari penyakit jantung, pengembangan akhlak mulia, membangun akhlak yang baik dalam pergaulan, dan mencapai kebahagiaan di dunia dan akhirat (Ahmad, 2018). Sabda Nabi Muhammad Saw. tentang kesehatan mental diriwayatkan oleh Tirmidzi, Abu Dawud, al-Bukhari, Ibnu Majah, dan Muslim (Fuad, 2016a). Hadis-hadis mengenai ibadah yang dilakukan akan berpengaruh terhadap jiwa, dikenal dengan psikoterapi melalui amalan ibadah (Ariadi, 2013). Hal ini menurut hadits mengandung permohonan perlindungan dari keburukan, sebab-sebab, dan tujuan-tujuannya, karena seluruh keburukan muncul dari jiwa, atau dari setan (Priyatna, 2014). Dalam al-Quran dan hadis ada banyak istilah yang berkaitan dengan jiwa manusia (Ariyanto, 2020). Kesejahteraan emosional (shihiyat al-nafs) dari sudut pandang yang luas adalah tujuan dari komposisi Nabi Muhammad Saw. dipilih sebagai utusan Allah Swt. (Fitrianah, 2018). Keimanan adalah interaksi psikologis yang menggabungkan setiap elemen dari roh, sentimen dan kontemplasi untuk dimasukkan ke dalam keyakinannya (Lubis, 2016).

Berdasarkan paparan di atas, penulis berusaha menyusun formula penelitian, yaitu rumusan masalah, pertanyaan penelitian, dan tujuan penelitian (Darmalaksana, 2020a). Rumusan masalah penelitian ini adalah terdapat hadis tentang kesehatan mental dengan pendekatan psikologi agama. Sedangkan pertanyaan secara terperinci yaitu bagaimana pandangan umum tentang kesehatan mental, bagaimana hadis tentang kesehatan mental, dan bagaimana kesehatan mental dengan pendekatan psikologi agama. Tujuan penelitian ini yakni membahas hadis tentang kesehatan mental dengan pendekatan psikologi agama. Penelitian ini diharapkan memiliki manfaat bagi pengayaan khazanah pengetahuan Islam.

\section{Metode Penelitian}

Penelitian ini menggunakan pendekatan kualitatif melalui studi pustaka (Darmalaksana, 2020b). Sedangkan metode yang digunakan adalah takjrij dan syarah hadis (Darmalaksana, 2020d). Pada tahapan syarah digunakan analisis kontemporer (Darmalaksana, 2020c). 
Jurnal Riset Agama, Volume 1, Nomor 2 (Agustus 2021): 308-322

Muhamad Azhan Azhari/ Dukungan Sosial bagi Penderita Disfungsional untuk Penguatan Kesehatan Mental: Studi Syarah Hadis dengan Pendekatan Psikologi Islam

\section{Hasil Penelitian dan Pembahasan}

Hasil dan pembahasan penelitian di bawah ini.

\section{Pandangan Umum Kesehatan Mental}

Kesehatan jiwa mencakup dua kata, yaitu kesehatan dan mental. Kata sehat pada dasarnya berasal dari kata sehat yang berarti tidak ada akibat atau penyakit yang mengganggu, termasuk disharmoni fisik dan psikis. Awal mula kata mental berasal dari bahasa latin mens atau mentis yang berarti roh, semangat kehidupan atau jiwa. Kesehatan dalam bahasa Yunani termasuk dalam kata hygiene yang menyiratkan wawasan kewaspadaan, jiwa, dan pikiran. Menurut organisasi kesehatan dunia (WHO) dari 4 orang 1 orang menderita gangguan jiwa, baik itu ringan atau berat. Dan biasanya mereka tidak menyadari gangguan tersebut. Mental adalah hal-hal yang berhubungan secara psikologis atau psikologis yang dapat mempengaruhi perilaku individu (Nurrohim, 2016). Menurut Zakiah Darajat, kesejahteraan psikologis adalah menjaga individu dari menghadapi indikasi masalah mental (neorose) dan manifestasi dari perilaku disfungsional (psychose). Definisi ini umumnya diterima oleh psikiater yang melihat orang menurut perspektif kesejahteraan atau penyakit. Sementara menurut Mustafa Fahmi ada dua makna kesejahteraan emosional, lebih spesifiknya pertama, kesehatan psikis terbebas dari indikasi perilaku disfungsional dan gangguan jiwa. Kedua, kesejahteraan emosional adalah cara yang berfungsi, luas, lengkap, tidak terbatas, individu memiliki hubungan dengan kapasitas individu untuk menyesuaikan diri dengan diri sendiri serta lingkungan setempat, keadaan mereka saat ini (Fuad, 2016b).

Kehidupan yang dijalani oleh setiap manusia mempunyai peristiwa yang dialami baik itu baik atau buruk. Kesehatan mental dipengaruhi oleh peristiwa dalam hidupnya, yang dapat berdampak signifikan pada perilaku dan kepribadiannya. Peristiwa ini dapat berupa kerabat, keluarga, pelecehan fisik, depresi, kecemasan, atau stress berat. Seseorang yang mengalami gangguan mental, mereka akan menghadapi kejengkelan dalam disposisi, kapasitas berpikir, dan kontrol penuh gairah yang dapat memicu perilaku buruk. Jika satu masalah mental yang tidak ditangani seperti yang diharapkan dapat memicu masalah mental lainnya, seperti merasa tidak bahagia dalam hidup atau sulit berinteraksi dari kehidupan sosial. Oleh karena itu, sudah saatnya untuk menjalankan pola hidup sehat, baik itu fisik maupun mental. Kesehatan emosional yang baik akan memberikan lingkungan yang tenang dan damai sehingga dapat menghargai kehidupan sehari-hari yang teratur dan menyukai orang-orang di sekitar (Ariadi, 2019b).

Kesehatan mental harus disadari oleh siapa pun, ketika mempunyai gangguan jiwa walaupun itu ringan, jika tidak diterapi atau diobati lambat 
Jurnal Riset Agama, Volume 1, Nomor 2 (Agustus 2021): 308-322

Muhamad Azhan Azhari/ Dukungan Sosial bagi Penderita Disfungsional untuk Penguatan Kesehatan Mental: Studi Syarah Hadis dengan Pendekatan Psikologi Islam

laun bisa menjadi gangguan jiwa yang berat. Gejala dan tanda masalah mental tergantung pada jenis gangguan mental yang dialami. Zakiah Darajat mengungkapkan ada dua faktor yang mempengaruhi kesehatan jiwa, yaitu faktor internal dan faktor eksternal. Faktor internal berasal dari faktor internal individu, antara lain kepribadian, kondisi fisik, kondisi psikologis, sikap terhadap masalah hidup dan keseimbangan mental. Faktor eksternal berasal dari orang luar, meliputi kondisi ekonomi, sosial dan alam, baik itu keluarga, lingkungan setempat maupun iklim pendidikan. Faktor eksternal yang baik dapat menjaga mental sehatnya seseorang, sebaliknya faktor eksternal yang tidak baik dapat berpotensi menimbulkan mental yang tidak sehat (Ariadi, 2019a).

Kesehatan jiwa adalah cabang ilmu yang membahas dan mengusahakan jiwa yang sehat (Nurrohim, 2016). Gangguan mental adalah gangguan serius yang dapat memengaruhi pemikiran, perasaan, dan perilaku seseorang. Menurut Kanfer dan Gouldstein, ciri-ciri orang dengan gangguan jiwa adalah: ada perasaan cemas dan tegang dalam dirinya; tidak puas dengan perilaku sendiri (dalam arti negatif); dan ketidakmampuan untuk menangani masalah secara efektif. Namun, terkadang ciri-ciri tersebut tidak dirasakan oleh penderitanya, melainkan oleh orang-orang di sekitarnya. Karena masyarakat sekitar merasa bahwa perilaku orang dengan gangguan jiwa akan merugikan diri sendiri. Efek yang dapat memicu gangguan jiwa, antara lain hubungan yang tidak memuaskan dengan orang lain, seperti diperlakukan tidak adil dan tidak mampu beradaptasi dengan situasi yang dihadapinya. Kemudian juga menderita penyakit tertentu sampai mengalami stres akibat peristiwa traumatis, seperti ditinggal mati oleh orang yang disayang, kehilangan pekerjaan, atau terisolasi dalam waktu yang lama. Terlebih lagi peristiwa-peristiwa yang dialami sejak pandemi Covid-19 juga sering dikaitkan dengan adanya gangguan mental pada seseorang. Masalah mental juga disebabkan oleh tekanan dari perasaan tidak mampu yang berlebihan. Alasan untuk kepercayaan diri yang rendah bisa menjadi ketidakmampuan untuk mencapai dominasi sepanjang kehidupan sehari-hari. Komponen yang dapat berdampak pada kesehatan mental yaitu perasaan, pikiran, dan kelakuan. Selain itu kesehatan badan juga dapat berpengaruh pada kesehatan mental. Di masa lalu banyak orang mengatakan bahwa mental yang kuat terletak pada tubuh yang sehat. Jadi kesehatan badan dan kesehatan mental terkait erat. Jika tubuh sedang lemah maka akan terganggu secara intelektual, dan sebaliknya jika kesehatan psikologis sedang terganggu maka fisik akan terasa sakit. Jadi menurut Zakiah Darajat, setiap individu harus memiliki pilihan untuk menyesuaikan kesehatan badan dan mental (Indah et al., 2020). 
Jurnal Riset Agama, Volume 1, Nomor 2 (Agustus 2021): 308-322

Muhamad Azhan Azhari/ Dukungan Sosial bagi Penderita Disfungsional untuk Penguatan Kesehatan Mental: Studi Syarah Hadis dengan Pendekatan Psikologi Islam

\section{Hadis tentang Kesehatan Mental}

Terdapat hadis Nabi Saw. berkenaan tentang kesehatan mental pada kitab Sahih al-Bukhari Nomor 5220:

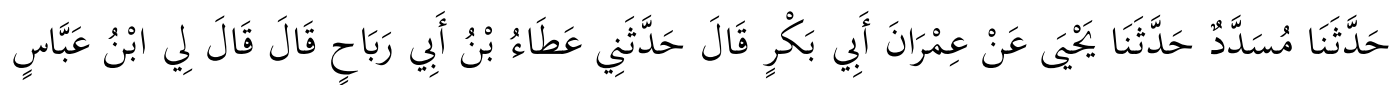

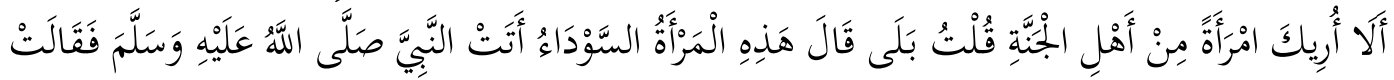

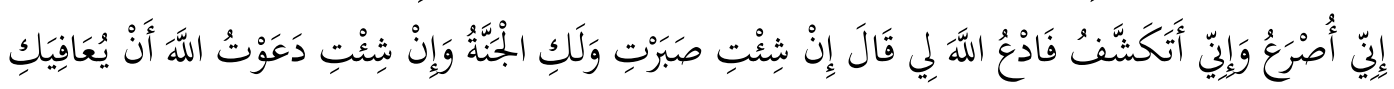

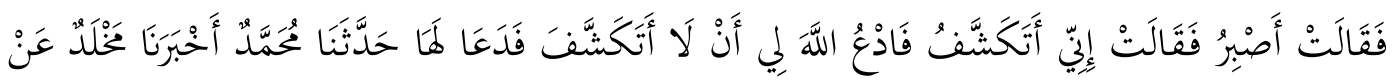

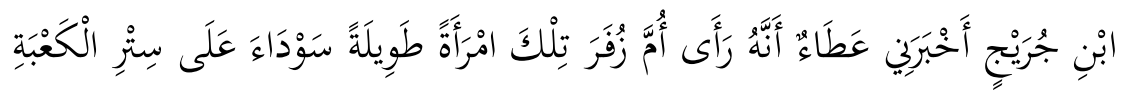

Telah menceritakan kepada kami Musaddad telah menceritakan kepada kami Yahya dari Imran bin Abu Bakar dia berkata: telah menceritakan kepadaku 'Atha' bin Abu Rabah dia berkata: Ibnu Abbas pernah berkata kepadaku: "Maukah aku tunjukkan kepadamu seorang wanita dari penduduk surga?" jawabku: "Tentu." Dia berkata: "Wanita berkulit hitam ini, dia pernah menemui Nabi shallallahu 'alaihi wa sallam sambil berkata: "Sesungguhnya aku menderita epilepsi dan auratku sering tersingkap (ketika sedang kambuh), maka berdoalah kepada Allah untukku." Beliau bersabda: "Jika kamu berkenan, bersabarlah maka bagimu surga, dan jika kamu berkenan, maka aku akan berdoa kepada Allah agar Allah menyembuhkanmu." Ia berkata: "Baiklah aku akan bersabar." Wanita itu berkata lagi: "Namun berdoalah kepada Allah agar (auratku) tidak tersingkap." Maka beliau mendoakan untuknya." Telah menceritakan kepada kami Muhammad telah mengabarkan kepada kami Makhlad dari Ibnu Juraij telah mengabarkan kepadaku 'Atha' bahwa dia pernah melihat Ummu Zufar adalah wanita tersebut, ia adalah wanita berpawakan tinggi, berkulit hitam sedang berada di tirai Ka'bah" (HR. al-Bukhari: 5220).

Mula-mula dilakukan pencarian pada aplikasi hadis dengan kata kunci "penyakit" hingga ditemukan hadis pada kitab Sahih Bukhari Nomor 5220, sebagaimana dikemukakan terdahulu.

Tabel 1. Daftar Rawi Sanad

\begin{tabular}{|c|c|c|c|c|c|c|c|}
\hline \multirow{2}{*}{$\begin{array}{l}\mathbf{N} \\
\mathbf{o}\end{array}$} & \multirow{2}{*}{$\begin{array}{l}\text { Rawi } \\
\text { Sanad }\end{array}$} & \multicolumn{2}{|c|}{ Lahir/Wafat } & \multirow[t]{2}{*}{ Negeri } & \multirow[t]{2}{*}{ Kuniyah } & $\begin{array}{l}\text { Komentar } \\
\text { Ulama }\end{array}$ & \multirow[t]{2}{*}{ Kalangan } \\
\hline & & $\mathbf{L}$ & $\mathbf{W}$ & & & - & \\
\hline 1 & $\begin{array}{l}\text { Abdullah } \\
\text { bin } \\
\text { 'Abbas } \\
\text { bin }\end{array}$ & $\begin{array}{l}3 \text { Th. } \\
\text { SH }\end{array}$ & $68 \mathrm{H}$ & $\begin{array}{l}\text { Marur } \\
\text { Rawdz }\end{array}$ & $\begin{array}{l}\text { Abu al- } \\
\text { 'Abbas }\end{array}$ & Tsiqah & Shahabat \\
\hline
\end{tabular}


Jurnal Riset Agama, Volume 1, Nomor 2 (Agustus 2021): 308-322

Muhamad Azhan Azhari/ Dukungan Sosial bagi Penderita Disfungsional untuk Penguatan Kesehatan Mental: Studi Syarah Hadis dengan Pendekatan Psikologi Islam

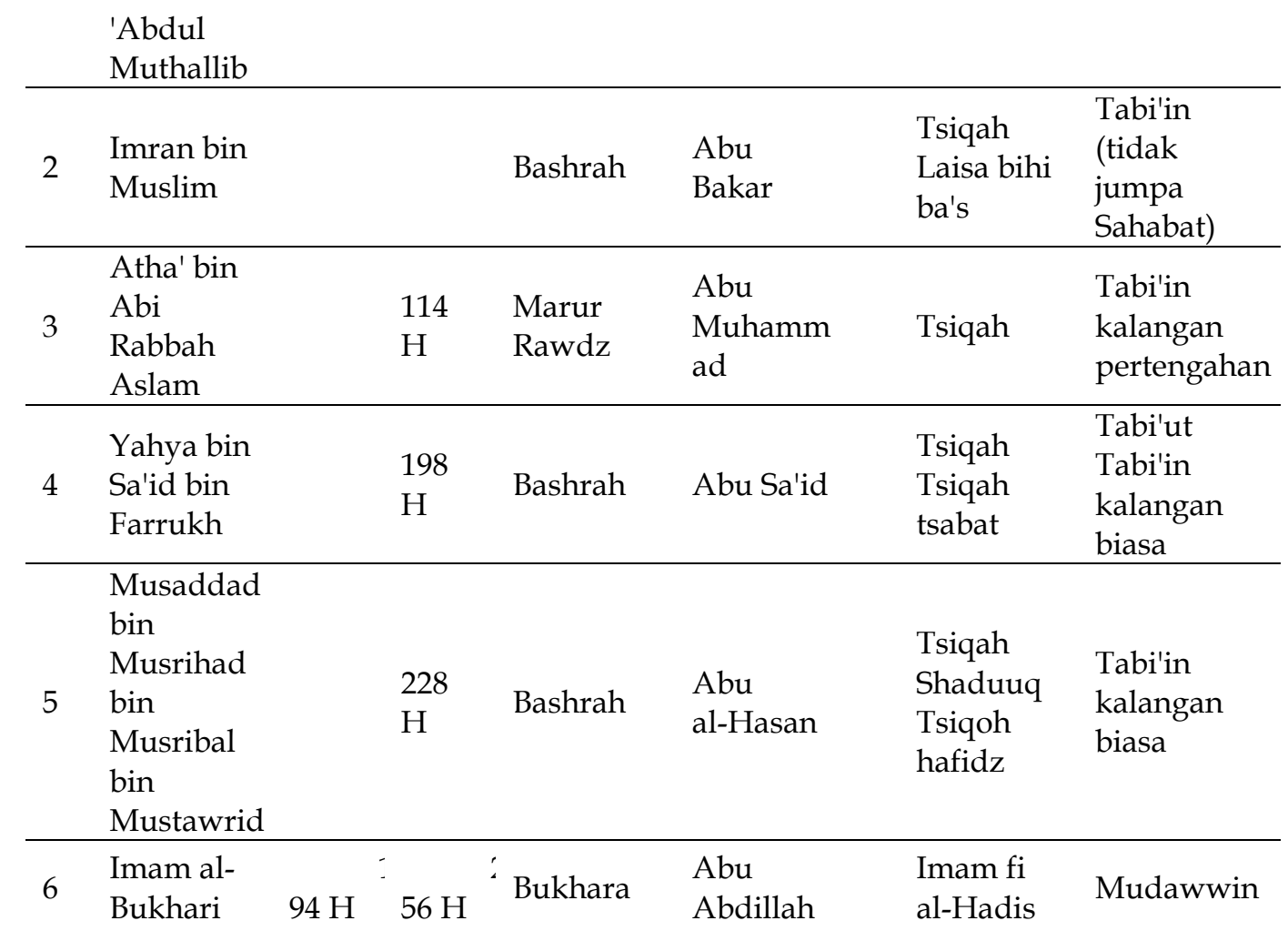

Tabel 1 adalah daftar rawi dan sanad dari hadits riwayat Bukhari yang sedang diteliti. Hadis dianggap sempurna jika memenuhi unsur penting yaitu rawi, sanad, mukharrij, shiyaghul ada' dan matan hadis. Kelima unsur tersebut sebagai pertimbangan penilaian riwayat hadis untuk menganalisa hadis apakah masuk ke dalam kategori shahih, hasan, atau dhaif. Rawi adalah periwayatan hadis sedangkan sanad adalah keseluruhan rawi (rantai periwayatan) dalam suatu hadis dengan sifat dan struktur yang ada (Rahman, 2010). Mukharrij adalah perawi terakhir yang mencatat riwayat yang diperoleh. Contoh hadis yang disebut mukharrij di atas adalah Imam Bukhari. Oleh karenanya Imam Bukhari dalam jalur sanadnya berkedudukan sebagai mukharrij al-hadis yakni orang yang meriwayatkan sekaligus membukukannya menjadi kitab hadis. Kemudian, shiyaghul ada' adalah metode penerimaan hadis atau redaksi yang digunakan oleh perawi ketika meriwayatkan hadits. Lafadz-lafadz seperti hadatsanna, 'an, qala, dan lain-lain. Redaksi-redaksi ini nantinya akan mempengaruhi kualitas dari sanadnya, khususnya sejauh apakah sanad itu bersambung kepada Nabi atau terputus. Dan matan adalah bunyi atau kalimat yang terdapat dalam hadits, yaitu isi dari riwayat, dengan kata lain matan adalah redaktur hadits. Maka dapat disimpulkan hadis yang diriwayatkan oleh al-Bukhari merupakan hadis shahih. Kriteria yang menentukan hadis dapat dikatakan shahih apabila hadis yang rantai sanadnya bersambung, periwayatan 
Jurnal Riset Agama, Volume 1, Nomor 2 (Agustus 2021): 308-322

Muhamad Azhan Azhari/ Dukungan Sosial bagi Penderita Disfungsional untuk Penguatan Kesehatan Mental: Studi Syarah Hadis dengan Pendekatan Psikologi Islam

bersifat 'adil dan dhabith, serta tidak terdapat kejanggalan (syadz) dan cacat ('illat) (Chandra \& Muhammad, 2016).

Dalam pandangan Islam, gangguan jiwa biasanya dianggap memiliki beberapa karakteristik buruk atau perilaku keji, seperti keserakahan, kecemburuan, kecemburuan, kesombongan, emosionalitas, dan lain-lain. Dalam kitab Nahw' Ilmiah Nafsi karya Hasan Muhammad as-Syarqawi, penyakit jiwa dibagi menjadi sembilan bagian, yaitu pamer (riya'), marah (al-ghadhab), lalai dan lupa (al-ghaflah wan nisyah), ragu-ragu (al-was-wasah), depresi (al-ya's), keserakahan (tama'), tertipu (al-ghurur), kesombongan (alujub), kecemburuan (al-hasd wal hiqd). Jika beberapa ciri di atas rata-rata dianggap sakit jiwa, maka relevan karena dalam kesehatan jiwa (mental hygiene), ciri-ciri tersebut merupakan tanda-tanda penyakit jiwa manusia (mental illness). Oleh karena itu, salah satu pasien gangguan jiwa ditandai dengan sifat-sifat buruk ini. Berdasarkan paparan hadis di atas seorang wanita berkulit hitam atau bisa disebut Ummu Zufar mendatangi Nabi Saw., dia hendak menanyakan penyakit yang dideritanya yaitu penyakit ayan (epilepsy). Epilepsi adalah penyakit kronis yang ditandai dengan kejang berulang yang sering tanpa alasan yang jelas. Munculnya penyakit epilepsi salah satunya terjadi karena gangguan emosional. Penderita epilepsi memang cenderung lebih mudah mengalami depresi, kecemasan, atau bahkan perilaku berusaha melukai dirinya sendiri. Kejang adalah aktivitas otak abnormal yang disebabkan oleh penyakit pada sistem saraf pusat (neurologis) sehingga membuat aktivitas otak menjadi tidak normal. Epilepsi biasanya melibatkan otak yang terpengaruhi oleh beberapa faktor seperti pengaruh genetik, cedera kepada kepala, kondisi otak, dan gangguan perkembangan. Beberapa gejala epilepsi yang paling umum termasuk kebingungan sementara di sebagian atau seluruh tubuh, kekakuan otot, tremor, atau kram. Namun, tidak hanya serangan epilepsi, epilepsi juga dapat merusak kesehatan sosial dan mental seseorang (Maryanti, 2016).

Berdasarkan paparan hadis di atas, Nabi mengatakan bahwa seseorang berkulit hitam tersebut memiliki gangguan mental. Nabi Saw. tidak mengatakan bahwa wanita tersebut kerasukan jin, atau wanita tersebut sebagai pendosa. Oleh sebab itu, atas penyakit yang dideritanya wanita tersebut merasakan frustasi karena penyakit ayan (epilepsy). Dalam konteks pembahasan hadis tersebut saat Ummu Zufar mempunyai penyakit ayan (epilepsy), Nabi Saw. mempunyai dua pilihan jawaban atas pertanyaannya yaitu jika berkanan bersabar dan surga bagimu atau Nabi Saw. akan berdoa kepada Allah Swt. agar Allah Swt. menyembuhkanmu. Kemudian Ummu Zufar memilih untuk bersabar, tetapi dia meminta Nabi untuk tidak memperlihatkan auratnya, maka Nabi mendoakannya. Ketika Allah SWT mendatangkan penyakit kepada manusia untuk berbagai maksud dan tujuan, redaksi hadis tersebut di atas. Maka kesabaran bisa 
Jurnal Riset Agama, Volume 1, Nomor 2 (Agustus 2021): 308-322

Muhamad Azhan Azhari/ Dukungan Sosial bagi Penderita Disfungsional untuk Penguatan Kesehatan Mental: Studi Syarah Hadis dengan Pendekatan Psikologi Islam

menerima diri menjadi pribadi yang lebih baik. Semua penyakit memiliki pengobatan yang diberikan oleh Allah. Namun, obat yang diberikan tidak selalu berupa fisioterapi. Dan juga bisa mengambil bentuk lain untuk menjadikan manusia lebih mulia. Secara umum, kesabaran sering diartikan sebagai keteguhan dalam menghadapi cobaan dan kesulitan, dan kegigihan dalam menghadapi cita-cita (Ariadi, 2019a).

Pada zaman dahulu semua sahabat ketika mempunyai permasalahan atau problematika dalam kehidupannya bertanya langsung kepada Nabi Saw. Karena, Nabi Saw. sebagai rujukan atau referensi utama dari segala problem permasalahan. Bukan hanya bertanya seputar kajian dalam hal ibadah, ada yang bertanya kepada Nabi Saw. terkait hal penyakit seperti Ummu Zufar. Dijelaskan dalam Q.S. al Anbiya (21) ayat 7, Allah Swt. berfirman; "Dan Kami tidak mengutus (rasul-rasul) sebelum engkau (Muhammad), melainkan beberapa orang laki-laki yang Kami beri wahyu kepada mereka, maka tanyakanlah kepada orang yang berilmu, jika kamu tidak mengetahui." Bagian tersebut diungkap dalam konteks tertentu, khususnya objek kajiannya sebagai kualitas manusia para Nabi dan Rasul yang diutus oleh Allah Swt. Jika redaksinya berbentuk umum, maka ayat ini dapat dipahami sebagai perintah untuk menanyakan sesuatu yang tidak diketahui oleh orang yang berilmu. Petikan ayat tersebut menjelaskan, bahwa Allah Swt. memerintahkan kepada orang yang tidak mengetahui supaya bertanya kepada orang yang berilmu. Bukan hanya soal ibadah, bertanya tentang masalah kesehatan mental pun sebaiknya bertanya kepada ahlinya. Bertanya atau berkonsultasi dengan psikolog dan psikiater. Namun, masih banyak terjadi kesalahpahaman, diskriminasi, dan stigma sosial yang negatif bagi penderita epilepsi. Sehingga penderita penyakit epilepsi merasa terjebak dalam kegelapan dan menutup diri. Orang yang memiliki gangguan mental sebenarnya memerlukan pertolongan dan dukungan yang baik dari orang sekitarnya. Meminta pertolongan itu bukanlah sebuah kelemahan tapi pada dasarnya manusia adalah makhluk sosial yang membutuhkan orang lain. Lebih khusus lagi penyakit epilepsi membutuhkan dukungan dari berbagai pihak sehingga kualitas hidupnya dapat meningkat (Susilaningsih et al., 2018).

\section{Kesehatan Mental dengan Pendekatan Psikologi Agama}

Psikologi agama merupakan salah satu bukti bahwa psikolog memberikan perhatian khusus pada peran agama dalam kehidupan manusia dan psikologi. Hipotesis dalam penelitian jiwa yang terkait dengan penelitian studi Islam digunakan untuk menjelaskan manifestasi lahiriah dari individu beragama. Pengertian psikologi agama adalah ilmu yang membahas tentang sikap dan perilaku seseorang ketika berinteraksi dengan lingkungan dan keyakinan tentang ajaran agamanya. Ada dua objek prinsip yang harus dipusatkan dalam penelitian jiwa tentang agama, 
Jurnal Riset Agama, Volume 1, Nomor 2 (Agustus 2021): 308-322

Muhamad Azhan Azhari/ Dukungan Sosial bagi Penderita Disfungsional untuk Penguatan Kesehatan Mental: Studi Syarah Hadis dengan Pendekatan Psikologi Islam

yaitu kesadaran agama dan pengalaman beragama. Kesadaran agama adalah bagian mental dari tindakan yang beragama, bagian dari bagian dari kehadiran atau pandangan terang agama, dan dapat dicoba dengan kesadaran. Pengalaman agama adalah komponen nyata dalam kesadaran agama, yang mendorong keyakinan dan minat dalam perilaku dan esensi sejati dari kehidupan yang beragama. Jadi penelitian jiwa tentang agama tidak lagi mengkaji hal-hal sentral atau pelajaran esensial dari suatu agama, melainkan dampak agama terhadap perilaku individu-individu yang menaruh bekal dalam suatu agama (Khoiruddin, 2017).

Sejarah Barat menunjukan perkembangan psikologi agama telah muncul di Barat sejak abad ke-19. Psikologi digunakan sebagai metode untuk memahami fenomena keagamaan; sikap, pola pikir, tradisi, dan lainlain. Manusia dapat menderita gangguan fisik karena gangguan jiwa (physical mental illness), sedangkan gangguan jiwa dapat menyebabkan penyakit fisik (mental-physical diseases). Ditentukan bahwa berbagai faktor spiritual yang dapat menyebabkan gejala ini adalah keyakinan agama. Ini sebagian karena beberapa dokter percaya bahwa penyakit mental tidak ada hubungannya dengan perawatan medis. Selain itu, banyak orang dengan penyakit mental dapat disembuhkan dengan metode agama. Ulama dan ahli biokimia Mahmud Abd al-Qadir memberikan bukti hubungan antara keyakinan agama dan kesehatan mental. Banyak orang telah menggunakan bantuan agama untuk mengobati penyakit mental (Hamid, 2017). Maka keberadaan agama bagi manusia merupakan sesuatu yang sangat penting untuk mengatasi probelamatika kejiwaan. Moreira, Neto, dan Koenig menyatakan bahwa keterlibatan seseorang yang beragama berpengaruh terhadap kesehatan mental (Moreira Almeida et al., 2006).

Kehidupan sehari-hari dijalani, serta berbagai masalah yang muncul seringkali menjadi beban pikiran seseorang. Beban yang tidak akan pernah terurai akan menumpuk seiring waktu dan menjadi masalah bagi jiwa dan mental. Dalam kehidupan sosial, masalah psikologis ini masih dianggap stigma yang buruk. Sehubungan dengan adanya stigma buruk dalam masyarakat, jika mempunyai kesehatan mental. Seseorang nantinya merasakan keraguan dalam dirinya apakah harus lebih mendekatkan diri pada Tuhan atau pergi ke mental health professional. Meminta tolong kepada psikolog atau psikiater tidak membuat tingkat keimanannya akan berkurang. Membutuhkan psikolog atau psikiater hanya salah satu cara membuat hidup menjadi lebih baik. Bercerita kepada teman atau kerabat mengenai masalah yang dialaminya merupakan salah satu bentuk untuk mengobati kesehatan mental. Sehingga membuat orang yang menderitanya akan merasakan ketenangan. Masyarakat sangat membutuhkan pelayanan psikologis yang murah dan terjangkau salah satunya melalui Puskesmas. Namun, hal itu sulit dicapai karena psikolog tidak termasuk dalam daftar tenaga kesehatan di bawah Kementerian Kesehatan (Sari, 2016). Para 
Jurnal Riset Agama, Volume 1, Nomor 2 (Agustus 2021): 308-322

Muhamad Azhan Azhari/ Dukungan Sosial bagi Penderita Disfungsional untuk Penguatan Kesehatan Mental: Studi Syarah Hadis dengan Pendekatan Psikologi Islam

psikolog saat ini sudah tersedia di Puskesmas walaupun belum merata di seluruh Indonesia. Status administrasi kesejahteraan emosional pada tahun 2010, Indonesia memberikan rincian mengenai kemajuan selama lima tahun terakhir, termasuk masuknya undang-undang kesejahteraan psikologis, pengaturan kesejahteraan emosional, rencana perawatan kesehatan psikologis area lokal, pengembangan pertemuan klien, menggabungkan kesehatan psikologis ke dalam kegiatan. Puskesmas, dan bantuan politik yang besar (Ayuningtyas et al., 2018).

Menurut teori ilmu, dalam Al-Quran dan hadits ada banyak istilah yang berkaitan dengan jiwa manusia (Ariyanto, 2020). Dampak besar agama dalam mengatasi permasalahan gangguan kesehatan ataupun permasalahan dalam hidupnya. Namun, setiap orang juga harus berhatihati dengan ajaran agamanya. Karena agama dapat memperburuk kesehatan mental seseorang, hal ini bersumber dari stigma kelompok agama. Menurut Wesselman dan Graziano adalah masih ada kelompok beragama yang melihat depresi sebelah mata. Karena orang yang depresi itu orang yang berdosa, atau ada gangguan dari setan. Orang yang sering memiliki masalah psikologis dianggap negatif atau bahkan dikucilkan. Maka akan muncul stigma buruk dari komunitas beragamanya seperti selfstigma. Pengertian self-stigma adalah proses seseorang menyetujui stigma hingga orang yang pengidap gangguan mental itu mengaplikasikannya ke diri sendiri. Orang-orang yang sudah percaya akan self-stigma nantinya tidak ingin mencari bantuan professional. Stigma diri sendiri sangat mungkin merupakan tanda rasa malu yang paling menyiksa dengan dampak yang berbahaya, dapat mempengaruhi dampak pengobatan bagi individu dengan ketidakstabilan psikologis (Suri \& Daryanto, 2019). Ketika orang yang mempunyai kesehatan mental diperlukan dukungan sosial dari komunitasnya. Malah jadinya orang yang memiliki stigma mulai mendiskriminasikan orang yang depresi, lebih parahnya orang mempunyai self-stigma mempunyai kepercayaan membuat individu tersebut mendiskriminasikan dirinya sendiri. Padahal ketika seseorang yang mengalami depresi, hal utama yang paling dibutuhkan adalah uluran tangan dan dukungan dari orang-orang sekitar. Stigma merupakan sesuatu hal yang tidak bisa diterima atau biasanya bersifat merendahkan dan menjatuhkan. Maka stigma buruk dari sekitar harus dihapus. Minimnya informasi tentang kesehatan mental tidak diragukan lagi sebagai penyebab utama stigma bagi individu dengan masalah mentalnya (Asti et al., 2016).

Agama seolah tidak bisa dipisahkan dari kehidupan manusia (Ariadi, 2019a). Beragam keyakinan dalam beragama pastinya memberikan manfaat bagi para penganutnya. Tidak semua orang dapat dengan tenang menghadapi penyakit yang dideritanya. Namun, jika seseorang mempunyai keyakinan pada Sang Pencipta, diyakini dapat membantu. Karena, ajaran agama menyiapkan cara menghadapi pengalaman buruk 
Jurnal Riset Agama, Volume 1, Nomor 2 (Agustus 2021): 308-322

Muhamad Azhan Azhari/ Dukungan Sosial bagi Penderita Disfungsional untuk Penguatan Kesehatan Mental: Studi Syarah Hadis dengan Pendekatan Psikologi Islam

dan tantangan hidup menjadi lebih baik. Selain itu ajaran agama juga menjauhkan dari cara penyelesaian masalah yang negatif. Penyimpangan dari norma-norma yang berlaku di masyarakat seperti mengonsumsi dan menggunakan narkoba ataupun alkohol, dan itu dilarang dalam agama. Orang yang beragama itu mempunyai tingkat self-stigma yang tinggi dibandingkan populasi umum. Maka agama dapat membantu pengikutnya menghindar dari depresi atau gangguan mental lainnya. Menurut psikiater Amerika Henry Link, orang yang menganut agama dan sering pergi ke tempat ibadah memiliki kepribadian yang lebih kuat dan lebih baik daripada orang yang tidak menjalankan ajaran agamanya. Oleh karena itu, orang dengan keyakinan agama yang tinggi memiliki kesehatan mental yang lebih baik daripada orang dengan keyakinan agama yang rendah. Tetapi, belum dapat dipastikan apabila orang memiliki kesehatan mental yang baik apakah karena mereka religius. Jawaban terbaik untuk mengatasi masalah kesehatan emosional adalah dengan melatih kualitas agama dalam kehidupan sehari-hari (Hamid, 2017).

\section{Kesimpulan}

Berbagai kalangan perlu menyadari kesehatan mental tidak hanya untuk orang dewasa yang sedang produktif, anak-anak, remaja bahkan orang tua harus sadar terhadap kesehatan mental. Karena kesehatan mental sesuatu yang tidak terlihat, tidak seperti kesehatan fisik. Jika kesehatan mental terganggu, kondisi fisik, dan kualitas hidup bisa menurun. Kesehatan mental dinilai dari hari-hari produktif yang hilang, sehingga kerja tidak maksimal, gangguan tidurnya, atau yang lain sebagainya. Trauma berat akibat suatu peristiwa atau gangguan fungsi otak dapat menyebabkan seseorang mengalami gangguan mental. Kesehatan itu sesuatu yang menyeluruh bukan hanya fisik saja, tetapi harus sehat mental, sosial, dan spiritual. Kesehatan fisik dipengaruhi oleh kesehatan mental. Ketika ada suatu perubahan dalam diri, terkadang sering melakukan tindakan untuk mendiagnosa kondisi pada diri sendiri (self-diagnosed). Seseorang tidak boleh mendiagnosa diri sendiri jika terkena gangguan mental, maka harus menemui psikolog atau psikiater supaya bisa mendapatkan diagnosa lebih lanjut, karena gangguan mental tidak dapat sembuh dengan sendirinya. Selain itu, psikolog atau psikiater merupakan sosok yang netral untuk mendengarkan dan memberi masukan. Jika memang belum yakin untuk ke psikolog, berbicaralah dengan keluarga atau sahabat supaya mendapatkan dukungan dari lingkungan sekitar. Kesadaran masyarakat dalam isu kesehatan mental terus meningkat. Dahulu mungkin masih menutup mata ketika membahas gangguan jiwa karena dianggap hal yang tabu. Tetapi kalau disadari, sekarang sudah banyak beberapa komunitas, obrolan di media sosial, bahkan karya film yang mengulas tentang kesehatan mental. Meskipun tenaga kesehatan 
Jurnal Riset Agama, Volume 1, Nomor 2 (Agustus 2021): 308-322

Muhamad Azhan Azhari/ Dukungan Sosial bagi Penderita Disfungsional untuk Penguatan Kesehatan Mental: Studi Syarah Hadis dengan Pendekatan Psikologi Islam

mental belum merata di seluruh Indonesia, tetapi para psikolog sudah ada di puskesmas, dan rumah sakit. Bahkan juga bisa berobat langsung kepada psikiater. Tetapi kesehatan mental masih dianggap stigma bagi beberapa orang. Beberapa masyarakat yang menganggap kesehatan mental adalah sesuatu yang aneh, bahkan dikira orang gila atau kerasukan setan. Maka kebiasaan stigma atau menilai yang buruk harus dihilangkan dalam benak setiap orang. Selanjutnya dalam penelitian ini, peran agama sangat penting dalam membentuk manusia yang sehat mental, sekaligus dapat menyembuhkan penderita gangguan mental. Ajaran agama dalam kehidupan sehari-hari dapat membentengi manusia dari gejala-gejala sakit jiwa. Karena dapat dikatakan bahwa orang beragama hidupnya lebih sehat dibanding yang tidak beragama. Hampir seluruh agama mengajarkan untuk menjauhi sumber stres dan penyebab penyakit. Ajaran, dan ritual menurut agama masing-masing dapat digunakan sebagai panduan untuk menjauhkan seseorang dari segala macam hal buruk. Dengan meminimalkan masalah dalam hidup setiap orang, maka seeorang akan merasakan ketenangan dan kemungkinan untuk menjalani kehidupan yang lebih bahagia. Islam menekankan pemeliharaan kesehatan mental, dimana hal ini dikemukakan oleh Al-Qur'an dan Hadis. Nabi Saw memirintahkan untuk bersabar dan berdoa agar tidak tertimpa gangguan mental. Penjalasan hadis terkait hal ini telah memberikan penguatan bagi bidang psikologi agama Islam. Diharapkan hasil penelitian ini dapat memberikan infromasi dan wawasan pengetahuan Islam bagi penderita maupun masyarakat umum tentang pentingnya kesehatan mental dengan pendekatan agama. Diakui penelitian ini memiliki segala aspek keterbasan dalam penyusunan, sehingga dibutuhkan penelitian lebih lanjut dari bidang psikologi dan ilmu kesehatan. Sebagai bahan terkait aspek psikososial dan konseling untuk menghilangkan stigma buruk dan memberikan sikap positif terhadap masyarakat umum tentang kesehatan mental. Penelitian ini direkomendasikan untuk dapat meningkatkan peran dan fungsi bagi khalayak umum bahwa penderita kesehatan mental membutuhkan dukungan dan moral dari lingkungan sekitar.

\section{Daftar Pustaka}

Ahmad, J. (2018). Muhasabah sebagai Upaya Mencapai Kesehatan Mental. Islamic Studies, December, 1-16.

Ariadi, P. (2013). Kesehatan Mmental dalam perspektif Islam. Syifa' MEDIKA, 3(2), 118-127.

Ariadi, P. (2019a). Kesehatan Mental dalam Perspektif Islam. Syifa' MEDIKA: Jurnal Kedokteran Dan Kesehatan, 3(2), 118-127.

Ariadi, P. (2019b). Kesehatan Mental dalam Perspektif Islam. Syifa' MEDIKA: Jurnal Kedokteran Dan Kesehatan, 3(2), 118. 
Jurnal Riset Agama, Volume 1, Nomor 2 (Agustus 2021): 308-322

Muhamad Azhan Azhari/ Dukungan Sosial bagi Penderita Disfungsional untuk Penguatan Kesehatan Mental: Studi Syarah Hadis dengan Pendekatan Psikologi Islam

https://doi.org/10.32502/sm.v3i2.1433

Ariyanto, M. D. (2020). Al-Qur'an dan Hadis sebagai Sumber Psikologi. SUHUF Universitas Muhammadiyah Surakarta, 32(1), 91-99.

Asti, A. D., Sarifudin, S., \& Agustin, I. M. (2016). Public Sigam terhadap Orang dengan Gangguan Jiwa di Kabupaten Kebumen. Jurnal Ilmiah Kesehatan Keperawatan, 12(3), 176-188.

Ayuningtyas, D., Misnaniarti, \& Rayhani, M. (2018). Analisis Situasi Kesehatan Mental pada Masyarakat di Indonesia dan Strategi Penanggulangannya. Jurnal Ilmu Kesehatan Masyarakat, 9(1), 1-10.

Chandra, A. F., \& Muhammad, B. (2016). Kriteria Ke-shahih-an Hadis menurut al-Khathib al-Baghdadi dalam Kitab al-Kifayah fi 'Ilm Riwayah. Jurnal Ushuluddin, 24(2), 162-174.

Darmalaksana, W. (2020a). Formula Penelitian Pengalaman Kelas Menulis. Jurnal Kelas Menulis UIN Sunan Gunung Djati Bandung. http:/ / digilib.uinsgd.ac.id/32620/

Darmalaksana, W. (2020b). Metode Penelitian Kualitatif Studi Pustaka dan Studi Lapangan. Pre-Print Digital Library UIN Sunan Gunung Djati Bandung.

Darmalaksana, W. (2020c). Penelitian Metode Syarah Hadis Pendekatan Kontemporer: Sebuah Panduan Skripsi, Tesis, dan Disertasi. Diroyah: Jurnal Studi Ilmu Hadis, 5.

Darmalaksana, W. (2020d). Prosiding Proses Bisnis Validitas Hadis untuk Perancangan Aplikasi Metode Tahrij. Jurnal Ushuluddin UIN Sunan Gunung Djati Bandung, 1, 1-7.

Fitrianah, R. D. (2018). Keseimbangan Emosi dan Kesehatan Mental Manusia dalam Perspektif Psikologi Agama. Dakwah IAIN Bengkulu, 18(1), 91-102.

Fuad, I. (2016a). Menjaga Kesehatan Mental Perspektif Al-Qur'an dan Hadits. Journal An-Nafs: Kajian Penelitian Psikologi, 1(1), 31-50. https:// doi.org/10.33367/psi.v1i1.245

Fuad, I. (2016b). Menjaga Kesehatan Mental Perspektif Al-Quran dan Hadits. Journal An-Nafs: Kajian Penelitian Psikologi, 1(1), 31-50. https:/ / doi.org/10.33367/psi.v1i1.245

Hamid, A. (2017). Agama dan Kesehatan Mental dalam Perspektif Psikologi Agama. Jurnal Kesehatan Tadulako, 3(1), 1-14.

Indah, S., Muqowim, \& Radjasa. (2020). Pemikiran Zakiah Darajat antara Kesehatan Mental dan Pendidikan Karakter. El-HiKMAH, 14(1), 42-80.

Khoiruddin, M. A. (2017). Pendekatan Psikologi dalam Studi Islam. Journal An-Nafs, 2(1), 1-17.

Lazuardini I, H. A. (2019). Relevansi Hadis Larangan Marah dengan Kesehatan Mental. AL QUDS : Jurnal Studi Alquran Dan Hadis, 3(1), 8196. https://doi.org/10.29240/alquds.v3i1.610

Lubis, A. (2016). Peran agama dalam kesehatan mental. Fakultas Tarbiyah 
Jurnal Riset Agama, Volume 1, Nomor 2 (Agustus 2021): 308-322

Muhamad Azhan Azhari/ Dukungan Sosial bagi Penderita Disfungsional untuk Penguatan Kesehatan Mental: Studi Syarah Hadis dengan Pendekatan Psikologi Islam

Dan Ilmu Keguruan UIN Sumatera Utara, 276-283.

Ma'rufah, Y. (2015). Manfaat Shalat terhadap Kesehatan Mental dalam AlQur'an. In Universitas Islam Negeri Sunan Kalijaga, Yogyakarta.

Maryanti, N. C. W. (2016). Epilepsi dan Budaya. Buletin Psikologi, 24(1), 2231. https://doi.org/10.22146/bpsi.16358

Moreira Almeida, A., Neto, F. L., \& Koenig, H. G. (2006). Religiousness and Mental Health: A Review. Rev Bras Psiquiatr, 28(3), 242-250. https:/ / doi.org/10.1017/S0890060414000201

Nurrohim, A. (2016). Antara Kesehatan Mental dan Pendidikan Karakter: Pandangan Keislaman Terintegrasi. Attarbiyah, I(2), 273-302. https:/ / doi.org/10.18326/attarbiyah.v1i2.273-302

Priyatna, M. (2014). Konsep Pendidikan Jiwa (Nafs) menurut Al-Quran dan Hadits. Edukasi Islam: Jurnal Pendidikan Islam, 03, 520-532.

Rahman, M. S. (2010). Kajian Matan dan Sanad Hadits dalam Metode Historis. Jurnal Ilmiah Al-Syir'ah, 8(2), 425-436. https:/ / doi.org/10.30984/as.v8i2.15

Reza, I. F. (2016). Efektivitas Pelaksanaan Ibadah dalam Upaya Mencapai Kesehatan Mental. Psikis : Jurnal Psikologi Islami, 1(1), 105-115.

Salsabila, A., \& Masrur, M. S. (2020). Peran Agama dalam Kesehatan Mental: Kajian Psikologis atas Kisah Maryam Binti Imran dalam QS Maryam: 18-22. Akademika UIN Sunan Kalijaga Yogyakarta, 14(2), 149160.

Sari, E. P. (2016). Upaya Pemberdayaan Komunitas melalui Sinergi Kader Posyandu dan Psikolog Puskesmas. Jurnal Ilmiah Psikologi Terapan, 04(01), 53-61.

Siregar, R. (2020). Pendekatan-pendekatan Islam untuk Mencapai Kesehatan Mental. AL-IRSYAD: Jurnal Bimbingan Konseling Islam, 2(2), 251-264.

Suri, M., \& Daryanto. (2019). Hubungan Harga Diri dan Stigma dengan Kualitas Hidup Pasien Skizofrenia di Klinik Jiwa RSJD Provinsi Jambi. Jurnal Ilmiah Kesehatan Pencerah, 08(2), 93-103.

Susilaningsih, F. S., Prawesti, A., \& Rahayu, D. (2018). Studi Deskriptif Kualitas Hidup Pasien Epilepsi pada Anak Usia Sekolah dan Remaja. Jurnal Keperawatan Aisyiyah, 5(2), 19-30. 